\title{
Knowledge and practice of nurses towards prevention of pressure ulcer and associated factors in Gondar University Hospital, Northwest Ethiopia
}

\author{
Nurhusien Nuru ${ }^{1 *}$, Fisseha Zewdu ${ }^{2+}$, Senafikish Amsalu ${ }^{3 \dagger}$ and Yohannes Mehretie ${ }^{4 \dagger}$
}

\begin{abstract}
Background: Pressure ulcers are the common conditions among patients hospitalized in acute and chronic care facilities and impose significant burden on patients, their relatives and caregivers. Pressure ulcers have been described as one of the most costly and physically debilitating complications since the $20^{\text {th }}$ century. The pain and discomfort due to pressure ulcer prolongs illness, rehabilitation, time of discharge and even contribute to disability and death. This study was aimed to assess knowledge, practice and factors associated with pressure ulcer prevention among nurses in Gondar University Hospital, North-west Ethiopia.
\end{abstract}

Method: An institution-based cross-sectional survey was conducted from March 15 - April 10, 2014 among 248 nurses in Gondar University hospital. A pretested and structured self-administered questionnaire was used for data collection. Data were entered using EPI info version 3.5.3 statistical software and analyzed using SPSS version 20 statistical package. Descriptive statistics was used to describe the study population in relation to relevant variables. Bivariate and multivariate logistic regression was also carried out to see the effect of each independent variable on the dependent variable.

Result: Nearly half (54.4\%) of the nurses had good knowledge; similarly $48.4 \%$ of them had good practice on prevention of pressure ulcer. Educational status [Adjusted Odds Ratio (AOR) $=2.4,95 \% \mathrm{Cl}$ (1.39-4.15)], work experience $[A O R=4.8,95 \% \mathrm{Cl}(1.31-10.62)]$ and having formal training $[A O R=4.1,95 \% \mathrm{Cl}(1.29-9.92)]$ were significantly associated with knowledge on prevention of pressure ulcer. While, satisfaction with nursing leadership [AOR $=1.9,95 \%$ $\mathrm{Cl}(1.04-3.82)]$, staff shortage $[A O R=0.07,95 \% \mathrm{Cl}(0.03-0.13)]$ and inadequate facilities and equipment $[A O R=0.4,95 \%$ $\mathrm{Cl}(0.19-0.83)]$ were found to be significantly associated with the practice on prevention of pressure ulcer.

Conclusion: Knowledge and practice of the nurses regarding prevention of pressure ulcer was found to be inadequate. Having higher educational status, attending formal training and being experienced were positively associated with knowledge; while shortage of facilities and equipments, dissatisfaction with nursing leadership and inadequate staff number showed negative association with practice of nurse's pressure ulcer prevention. In-service training and upgrading courses are some of the important steps to improve nurses' knowledge and practice on prevention of ulcer pressure.

Keywords: Pressure ulcer, Knowledge and practice

\footnotetext{
* Correspondence: nurusennuru@gmail.com

${ }^{\dagger}$ Equal contributors

${ }^{1}$ Emergency Department, Metema Hospital, Gondar, Ethiopia

Full list of author information is available at the end of the article
} 


\section{Background}

Pressure ulcers are the common conditions among patients hospitalized in acute and chronic care facilities and impose a significant burden on patients, their relatives and caregivers [1]. Now days, pressure ulcers are recognized worldwide as one of the five most common causes of harm to patients and preventable patient safety problem. Also increasingly described as an indicator of the quality of care provided by health care organizations [2-4].

Pressure ulcers have been described as one of the most costly and physically debilitating complications since the $20^{\text {th }}$ century. The pain and discomfort of pressure ulcer delays rehabilitation, prolongs illness and timing of discharge, and also contribute to disability and death. These dramatically raise health care costs as a result of the need for supplies and nursing hours [5]. Moreover, health care budgets expend billion of dollars worldwide on prevention and treatment of patients with extended hospital stays from pressure ulcer development [6]. It has been estimated that the cost of treating pressure ulcer is 2.5 times higher than the cost of preventing [7]. In USA, pressure ulcers remain a major health problem affecting approximately 3 million adults [8]. A systematic review of 31 studies found that pressure ulcers significantly limit many aspects of an individual's wellbeing, including general health and physical, social, financial and psychological quality of life [9]. So, the burden of pressure ulcers goes beyond increasing health care costs to loss of life [10].

According to an international literature, it has been identified that nurses' knowledge of the prevention of pressure ulcers is poor, which is reflected in their practices as they do not comply with best practice guidelines [11]. Study conducted in Sweden on nurses' knowledge and practice of existing guidelines on prevention of pressure ulcer found that, majority of them had inadequate knowledge and practice to implement guidelines [12]. Similarly, a study in Belgian Hospital found that knowledge of nurses about the prevention of pressure ulcers was inadequate [13]. Poor knowledge and practice of nurses have its own significant contribution for higher prevalence of pressure ulcers [14]. Moreover, a study in Bahir Dar, Ethiopia found that a total of 71 pressure ulcers were detected in 422 patients, with the prevalence rate of $16.8 \%$. The prevalence of pressure ulcer was higher in male respondents than in female respondents [15].Because, even if the prevention of pressure ulcers is a multidisciplinary responsibility, usually nurses play a major role and it is considered to be an essential part of nursing care in high income countries. Thus preventing ulcer should be the goal of all nurses [16] but it is rarely researched in low income countries like Ethiopia.

In Ethiopia there is lack of evidence on nurses' knowledge and practice of pressure ulcer prevention. Therefore, this study set out to assess the level of nurses' knowledge and practice on prevention of pressure ulcer and thereby generate appropriate information that can be used by program managers and stakeholders in the prevention and interventions of pressure ulcer.

\section{Methods}

\section{Study design and set up}

An institutional based cross sectional study was conducted among nurses working in Gondar University hospital. The hospital is located in Gondar town, Amhara regional state Northwest Ethiopia. Gondar is $740 \mathrm{~km}$ from the capital Addis Ababa. The hospital was established in 1954 and provides outpatient and inpatient services for more than 5 million peoples living in its catchment area.

\section{Sample size and sampling procedure}

The sample size was determined by using single population proportion formula with the assumption of: $50 \%$ proportion, $95 \%$ confidence level and $5 \%$ margin of error. Given that the source population was less than 10,000 correction formula was used and $5 \%$ nonresponse was added, making the final sample size 201 . Since the total number of nurses working in the hospital was 255 , the study involved all of them to increase the power of the study.

\section{Data collection tool and procedure}

Data were collected using a structured and pretested self administered questionnaire. The questionnaire and the consent form were prepared in English. Participants were asked 22 knowledge based and 22 practice based questions to assess their level of knowledge and practice towards prevention of pressure ulcer. Four midwife nurses and Public Health Officers collected the data with close supervision. Data quality was controlled by giving trainings and appropriate supervisions for data collectors. The overall supervision was carried out by the principal investigator. A pre-test was conducted using $6 \%$ of the questionnaire on nurses who were working in Bahir Dar Referral Hospital. Appropriate modifications were made after analyzing the pretest result before the actual data collection.

The appropriateness of the instrument was measured through a pre-testing exercise, and the constraining factors were rectified. Prior to applying the survey instrument, the researchers engaged different expert reviewers as subject matter specialists at Gondar University Hospital to evaluate and finalize the instrument. Regarding to the reliability, the study used Cronbach's coefficient alpha to measure consistency, complementarily and correlation coefficient. To generate the Cronbach's alpha results, validation of the instrument was conducted through a pilot 
study and the results obtained had an overall Cronbach's alpha of $(r)=0.76$.

\section{Operational definitions \\ Pressure ulcer}

a lesion of skin or underlying tissues by direct unrelieved pressure for more than 3 hours on the skin.

\section{Good knowledge}

Nurses, who scored above the mean score of the knowledge questions, were considered as having good knowledge on pressure ulcer prevention. But in the contrarily, those scored below the mean value considered as having poor knowledge towards prevention of pressure ulcer.

\section{Good practice}

Nurses who scored above the mean score of the practice questions related to prevention of pressure ulcer were considered to have good practice. But in the contrarily, those who scored below the mean score were considered as having poor practice towards prevention of pressure ulcer.

\section{Data processing and analysis}

The questionnaires filled by the nurses were checked for completeness and entered into EPI INFO version 3.5.3 statistical software and then exported to SPSS version 20 for further analysis. Descriptive statistics was used to describe the study population in relation to relevant variables. Both bivariate and multivariate logistic regression models were used to identify associated factors. Odds Ratios and their $95 \%$ Confidence Intervals were computed and variables with $\mathrm{p}$ - value less than 0.05 were considered as significantly associated with the outcome variable.

\section{Ethical considerations}

Ethical clearance was obtained from University of Gondar, Ethical Review Committee of Department of Nursing. A formal letter of cooperation was written to Gondar University Hospital. After the purpose and objective of the study had informed, verbal consent was obtained from each study participant. Data were kept anonymously in the distributed questionnaire in order to keep confidentiality.

\section{Results}

Socio-demographic characteristics of the study participants

Out of the expected 255 respondents, 248 agreed to participate in the study, yielding a response rate of $97.3 \%$. The mean age of the respondents was 28.25 years $(\mathrm{SD}=$ 5.1). Around half $(53.6 \%)$ were single. Nearly half of them $(50.8 \%)$ were males, two third $(62.5 \%)$ of the nurses had bachelor degree. Most (92.7 \%) had working experience of less than 10 years (Table 1 ).

\section{Organizational factors on prevention of pressure ulcer}

Majority $(91.1 \%)$ of the nurses had not received any formal training and $223(89.9 \%)$ of them were not using any existing guidelines about risk assessment and prevention of pressure ulcer. More than half of the nurses $(53.2 \%)$ were not satisfied with the nursing leadership of the hospital. More than three quarter $(78.6 \%)$ of the nurses disagreed to the time given for each patient care. While Less than half (43.5\%) of the nurses reported staff shortage, big majority $(88.3 \%)$ of them agreed the hospital had inadequate facilities and equipments (Table 2).

\section{Knowledge of pressure ulcer prevention}

Participants were asked 22 questions to assess their knowledge on pressure ulcer prevention, and they were categorized in to two groups based on their score in relation to the mean. The mean score was 12.79 ( $\mathrm{SD}=$ 3.21). More than half $(54.4 \%)$ of the respondents were found to have good knowledge, while a substantial proportion (45.6\%) of the respondents were not (Fig. 1).

From the six dimensions of knowledge regarding prevention of pressure ulcer, the nurses had a poor knowledge on three including risk assessment, skin care and management for mechanical loads. But, they possessed a good knowledge on factors related to pressure ulcer formation $(M=71.9, S D=25.2)$, benefit of nutrition to maintain healthy skin $(M=69.9, S D=29.1)$ and importance of staff training $(\mathrm{M}=60.7, \mathrm{SD}=34.2)$ (Table 3).

Nurses' practice regarding to prevention of pressure ulcer By using 22 practice based questions, the mean practice score of the respondents was found to be 12.16 ( $\mathrm{SD}=$ 9.75) (Table 4). Nearly half (48.4\%) of the respondents had good practice; whereas the remaining $51.6 \%$ respondents had poor practice of pressure ulcer prevention (Fig. 1).

\section{Factors associated with nurses' knowledge regarding to prevention of pressure ulcer}

Level of education, length of work experience and formal training on prevention of pressure ulcer were found to have significant and independent effect on nurses' knowledge regarding to prevention of pressure ulcer, while availability of guidelines about pressure ulcer prevention was not significantly associated at $\mathrm{p}$-value of $<=0.05$.

Those nurses who had bachelor degree were 2.4 times $[\mathrm{AOR}=2.4,95 \% \mathrm{CI}(1.39-4.15)]$ more likely to have a good knowledge on prevention of pressure ulcer as compared to those nurses who had diploma. Nurses who had work experience of 11-20 years were 4.8 times 
Table 1 Percentage distribution of the study participants by of Socio Demographic Characteristics, Gondar University Hospital, Northwest Ethiopia, 2014

\begin{tabular}{llll}
\hline Variables & $\begin{array}{l}\text { Frequency } \\
(\mathrm{n}=248)\end{array}$ & $\begin{array}{l}\text { Percentage } \\
(100 \%)\end{array}$ & Mean with SD \\
\hline Sex & 126 & 50.8 \\
Male & 122 & 49.2 & \\
Female & 206 & 83.1 & $28.25 \pm 5.1$ \\
Age (in years) & 31 & 12.5 & \\
20-30 & 11 & 4.4 \\
$31-40$ & 133 & 53.6 \\
$\geq 41$ & 122 & 45.2 \\
Marital status & 3 & 1.2 \\
Single & & \\
Married & & \\
Divorced & 93 & 37.5 \\
Level of \\
education
\end{tabular}

[AOR $=4.8,95 \%$ CI (1.31-10.62) $]$ more likely to have good knowledge than nurses with less than 10 years of work experience.

Those nurses who had formal training about pressure ulcer were 4.1 times $[\mathrm{AOR}=4.1,95 \% \mathrm{CI}$ (1.29-9.92)] more likely to have good knowledge than those nurses who did not took training about pressure ulcer (Table 5).

\section{Factors associated with nurses' practice of pressure ulcer prevention}

Satisfaction with nursing leadership, Having formal training on pressure ulcer prevention, staff shortage and inadequate facilities and equipments were found to have significant and independent effect on practice of nurses' towards prevention of pressure ulcer, while level of education, length of work experience were not significantly associated at $\mathrm{p}$-value of $<=0.05$.

Nurses who were satisfied with nursing leadership were around 2 times $[\mathrm{AOR}=1.9,95 \% \mathrm{CI}$ (1.04-3.82)] more likely to have good practice of pressure ulcer prevention when compared to those who were not. Study participants who agreed about staff shortage in the work place were $93 \%$ [AOR $=0.07,95 \%$ CI (0.03-0.13) $]$ less likely to have good practice than nurses who disagreed about the shortage of staff. Moreover, respondents who
Table 2 Percentage distribution of nurses' organizational factors, Gondar University Hospital, Northwest Ethiopia, 2014

\begin{tabular}{lll}
\hline Variables & Frequency $(\mathrm{n}=248)$ & Percentage (\%) \\
\hline $\begin{array}{l}\text { Formal training on } \\
\text { pressure ulcer }\end{array}$ & & \\
Yes & 22 & 8.9 \\
No & 226 & 91.1 \\
Guidelines on & \\
pressure ulcer & & \\
Yes & 25 & 10.1 \\
No & 223 & 89.9 \\
Nursing leadership & & \\
Satisfied & 116 & 46.8 \\
Not satisfied & 132 & 53.2 \\
Time for patients & & \\
Agree & 53 & 21.4 \\
Disagree & 195 & 78.6 \\
Staff shortage & & \\
Agree & 108 & 43.5 \\
Disagree & 140 & 56.5 \\
Inadequate facilities & & 11.7 \\
and equipments & & \\
Agree & 219 & \\
Disagree & 29 & \\
\hline
\end{tabular}

agreed about inadequate facilities and equipments in the work place were $60 \%$ [AOR =0.4, $95 \%$ CI (0.19-0.83)] less likely to have good practice towards prevention of pressure ulcer as compared to those who were disagree about inadequate facilities and equipments (Table 6).

\section{Discussion}

Prevention of pressure ulcers is an indicator of quality of care. Nursing care has a major effect on pressure ulcer development and prevention. Hence, Pressure ulcers are a major nurse-sensitive outcome [16]. So this study was

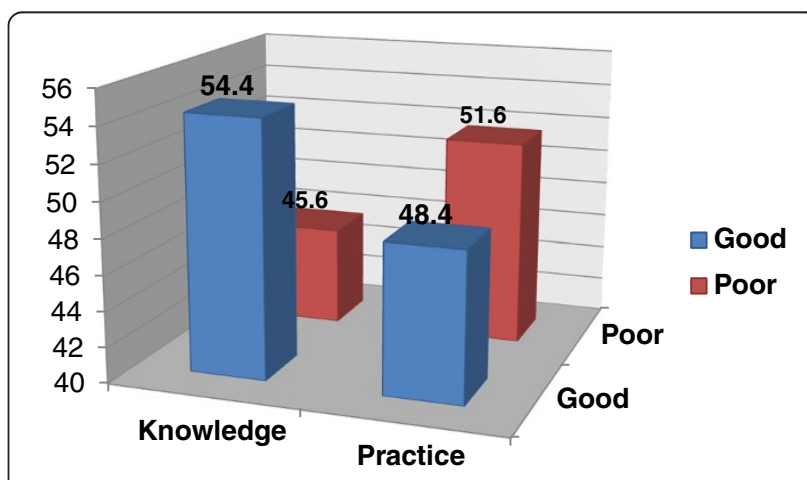

Fig. 1 Nurses' knowledge and practice regarding to prevention of pressure ulcer, Gondar University Hospital, Northwest Ethiopia, 2014 
Table 3 Frequency and percentage distribution of the nurses' knowledge on prevention of pressure ulcer ( $N=248)$ in $\mathrm{Gondar}$ University Hospital, Northwest Ethiopia, 2014

\begin{tabular}{|c|c|c|c|c|}
\hline \multirow[t]{3}{*}{ Nurses knowledge regarding to pressure ulcer } & \multicolumn{4}{|c|}{$\begin{array}{l}\text { Rate of nurse's } \\
\text { knowledge }\end{array}$} \\
\hline & \multicolumn{2}{|c|}{ Correct } & \multicolumn{2}{|c|}{ Incorrect } \\
\hline & n & $\%$ & n & $\%$ \\
\hline 1. High loading pressure is the contributing factor for pressure ulcer formation & 175 & 70.6 & 73 & 29.4 \\
\hline $\begin{array}{l}\text { 2. Immobility is the most important factor for pressure ulcer Formation in an } 80 \text { - years old man with fracture hip and } \\
\text { bedridden }\end{array}$ & 158 & 63.7 & 90 & 36.3 \\
\hline $\begin{array}{l}\text { 3. Feces is the favorable environment for bacterial growth in the form of maceration for a young man having head injury } \\
\text { with unconsciousness }\end{array}$ & 184 & 74.2 & 64 & 25.8 \\
\hline 4. Low albumin is the critical determinant for pressure ulcer formation & 196 & 79.0 & 52 & 21.0 \\
\hline $\begin{array}{l}\text { 5. Head to toe skin assessment is an assessment procedure for a patient with spinal cord injury who is at high risk for } \\
\text { pressure ulcer development }\end{array}$ & 150 & 60.5 & 98 & 39.5 \\
\hline 6. Braden scale is the risk assessment scale for pressure ulcer development & 138 & 55.6 & 110 & 44.4 \\
\hline 7. Risk assessment scale is an appropriate method for assessing an individual who is at risk for pressure ulcer development & 125 & 50.4 & 123 & 49.6 \\
\hline 8. Partial skin loss with blister and abrasion is correct answer for the sign of stage II pressure ulcer & 199 & 80.2 & 49 & 19.8 \\
\hline 9. Pale, red, or blue - gray discoloration on the skin is the sign for pressure ulcer development & 97 & 39.1 & 151 & 60.9 \\
\hline 10. Topical cream is appropriate method for skin care & 40 & 16.1 & 208 & 83.9 \\
\hline 11. Turn position for every 2 hours is significant activity for protecting skin damage & 194 & 78.2 & 54 & 21.8 \\
\hline $\begin{array}{l}\text { 12. Cleansing soil and using skin barrier cream or lotion activity is appropriate for preventing maceration for a } 78 \text { - years } \\
\text { old man having a stroke with hemiplegic }\end{array}$ & 147 & 59.3 & 101 & 40.7 \\
\hline 13. Lift up the patient without dragging is a correct practice for maintaining skin integrity & 96 & 38.7 & 152 & 61.3 \\
\hline 14. Use pillow under the patients leg to prevent heel ulcer & 69 & 27.8 & 179 & 72.2 \\
\hline 15. Vitamin $C$ and $E$ is important to maintain healthy skin & 194 & 78.2 & 54 & 21.8 \\
\hline 16. High protein and high calorie needs to be offered to a 85 - years Old bedridden patient who has $\mathrm{BMI}<18.5$ & 167 & 67.3 & 81 & 32.7 \\
\hline 17. Serum albumin is an appropriate lab test for nutritional assessment of pressure ulcer patient & 159 & 64.1 & 89 & 35.9 \\
\hline 18. Turn position is an appropriate nursing care for managing mechanical load & 159 & 64.1 & 89 & 35.9 \\
\hline $\begin{array}{l}\text { 19. Lift patient without dragging is appropriate activity to reduce friction for an } 80 \text { - years old man having fracture hip } \\
\text { with skeletal traction }\end{array}$ & 160 & 64.5 & 88 & 35.5 \\
\hline 20. Elevate the head of bed $<30^{\circ}$ is the activity for reducing shearing force & 66 & 26.6 & 182 & 73.4 \\
\hline 21. Schedule of Turing position is necessary educational Information for reducing pressure ulcer formation & 168 & 67.7 & 80 & 32.3 \\
\hline $\begin{array}{l}\text { 22. In- service training on pressure ulcer prevention is the best Educational activity that enhances competency of staff } \\
\text { nurses in preventing pressure ulcer }\end{array}$ & 133 & 53.6 & 115 & 46.4 \\
\hline
\end{tabular}

aimed to describe the level of nurse's knowledge and practice on prevention of pressure ulcers and its associated factors in Gondar University Hospital, Northwest Ethiopia.

In this study, $54.4 \%$ of the participants were found to be knowledgeable. While substantial proportions $45.6 \%$ were not, this is inadequate. Because, as they are nurses working in recognized teaching referral hospital, and are expected to be well experienced, this level of knowledge is below the anticipated. The finding of this study is comparable with other studies conducted in different parts of the world. In a study conducted in Turkey the mean score of correct answer was $48.85 \%$ [17] and the study conducted in Belgian hospital revealed that the mean knowledge score was $49.7 \%$ [13]. Similarly, the study conducted in Bangladesh indicated that the overall nurses' knowledge on pressure ulcer prevention were found to be $57.79 \%$ [18] and the other study conducted in one of the largest health insurance hospital in Alexandria, found that, the overall mean percentage score for nurses were below the minimum acceptable level [19].

Respondent's formal education and training experience may be a factor related to this poor level of knowledge. Pressure ulcer prevention related content included in their curriculums might not be sufficient. In addition, lack of learning resources for nurses to update their knowledge would be another reason for the poor level of knowledge. Specifically in Ethiopia, there is a limited learning resource for nurses to update their knowledge. Moreover nursing journals are not available even at the nursing institutes or hospitals. Specific to this study 91.1 $\%$ of the participants had not received any formal 
Table 4 Frequency and percentage distribution of nurses' practice on prevention of pressure ulcer $(\mathrm{N}=248)$ in Gondar University Hospital, Northwest, 2014

\begin{tabular}{|c|c|c|c|}
\hline \multirow{2}{*}{$\begin{array}{l}\text { Nurses practice on pressure ulcer } \\
\text { prevention }\end{array}$} & \multicolumn{3}{|c|}{ Rate of nurse's practice } \\
\hline & $\begin{array}{l}\text { Always } \\
(\%)\end{array}$ & $\begin{array}{l}\text { Sometimes } \\
(\%)\end{array}$ & $\begin{array}{l}\text { Never } \\
(\%)\end{array}$ \\
\hline $\begin{array}{l}\text { 1. I Observe how other nurses assess } \\
\text { the risk factors }\end{array}$ & 4.8 & 42.3 & 52.9 \\
\hline $\begin{array}{l}\text { 2. I identify common contributing } \\
\text { factors }\end{array}$ & 8.1 & 41.1 & 50.8 \\
\hline 3. I do a skin assessment & 5.2 & 18.1 & 76.7 \\
\hline 4. I use risk assessment scale & 5.6 & 14.9 & 79.5 \\
\hline 5. I document all data & 12.9 & 17.7 & 69.4 \\
\hline $\begin{array}{l}\text { 6. I assess and provide management } \\
\text { of pain }\end{array}$ & 41.1 & 30.6 & 28.3 \\
\hline 7. I perform skin care as a routine work & 15.7 & 44.4 & 39.9 \\
\hline $\begin{array}{l}\text { 8. I place the pillow under the } \\
\text { patient's leg }\end{array}$ & 7.3 & 32.7 & 60.0 \\
\hline $\begin{array}{l}\text { 9. I use water filled glove under } \\
\text { the patient's leg }\end{array}$ & 6.5 & 31.0 & 62.5 \\
\hline $\begin{array}{l}\text { 10. I use or advice caregiver to use } \\
\text { creams or oils }\end{array}$ & 4.4 & 28.6 & 67.0 \\
\hline $\begin{array}{l}\text { 11. I pay more attention to pressure } \\
\text { points }\end{array}$ & 17.7 & 32.3 & 50.0 \\
\hline 12. I perform lab tests & 5.2 & 13.3 & 81.5 \\
\hline 13. I provide vitamin and food & 8.9 & 30.2 & 60.9 \\
\hline 14. I monitor a protein and calorie diet & 4.0 & 27.4 & 68.6 \\
\hline 15. I avoid dragging & 39.5 & 23.8 & 36.7 \\
\hline 16. I always use a special mattress & 10.9 & 21.0 & 68.1 \\
\hline 17. I avoid massage & 42.7 & 18.1 & 39.2 \\
\hline $\begin{array}{l}\text { 18. I avoid using donut - shape } \\
\text { (ring) cushion }\end{array}$ & 34.7 & 23.8 & 41.5 \\
\hline $\begin{array}{l}\text { 19. I turn a patient position every } \\
\text { two hours. }\end{array}$ & 12.9 & 31.9 & 55.2 \\
\hline $\begin{array}{l}\text { 20. I put pillows under the patient's } \\
\text { leg ankle }\end{array}$ & 8.1 & 27.8 & 59.1 \\
\hline 21. I always attend seminars & 4.4 & 15.7 & 79.9 \\
\hline $\begin{array}{l}\text { 22. Give advice to the patient or } \\
\text { caregiver }\end{array}$ & 8.9 & 30.6 & 60.5 \\
\hline
\end{tabular}

training and $89.9 \%$ of the nurses were not using any existing guidelines on risk assessment and prevention of pressure ulcer.

Respondent's level of education was found to be significantly associated with knowledge of pressure ulcer prevention. This finding is in line with the study conducted in Sweden among registered nurses and licensed practicum nurses in which the registered nurses' score were significantly higher than those of the licensed practicum nurses [20]. This could be attributed to the possibility that more educated respondents have a higher opportunity of exposure to different courses directly or indirectly related to prevention of pressure ulcer.
Table 5 Bivariate and Multivariate analysis of factors associated with nurses' knowledge regarding to prevention of pressure ulcer, Gondar university Hospital, Northwest Ethiopia, 2014

\begin{tabular}{|c|c|c|c|c|}
\hline & \multicolumn{4}{|l|}{ Knowledge } \\
\hline & Good, n (\%) & Poor, n (\%) & COR $(95 \% \mathrm{Cl})$ & AOR $(95 \% \mathrm{Cl})$ \\
\hline \multicolumn{5}{|l|}{$\begin{array}{l}\text { Level of } \\
\text { education }\end{array}$} \\
\hline Diploma & $39(41.9)$ & $54(58.1)$ & 1.00 & 1.00 \\
\hline Bachelor & $96(61.9)$ & $59(38.1)$ & $2.3(1.33-3.81)$ & $2.4(1.39-4.15)$ \\
\hline \multicolumn{5}{|l|}{$\begin{array}{l}\text { Work } \\
\text { experience }\end{array}$} \\
\hline $1-10$ & $120(52.2)$ & $110(47.8)$ & 1.00 & 1.00 \\
\hline $11-20$ & $15(83.3)$ & $3(16.7)$ & $4.6(1.29-10.26)$ & $4.8(1.31-10.62)$ \\
\hline \multicolumn{5}{|l|}{ Training } \\
\hline Yes & 18(81.8) & $4(18.2)$ & 4.2(1.38-9.78) & $4.1(1.29-9.92)$ \\
\hline No & $117(51.8)$ & 109(48.2) & 1.00 & 1.00 \\
\hline \multicolumn{5}{|l|}{ Guidelines } \\
\hline Yes & $20(80.0)$ & $5(20.0)$ & $3.8(1.36-10.36)$ & \\
\hline No & 115(51.6) & $108(48.4)$ & 1.00 & * \\
\hline
\end{tabular}

Table 6 Bivariate and Multivariate analysis of factors associated with nurses' practice regarding to prevention of pressure ulcer, Gondar University Hospital, Northwest Ethiopia, 2014

\begin{tabular}{lllll}
\hline Variables & Practice & & & \\
& Good, $\mathrm{n}$ & Poor, $\mathrm{n}$ & COR $(95 \% \mathrm{Cl})$ & $\mathrm{AOR}(95 \% \mathrm{Cl})$ \\
\hline Level of education & & & & \\
Diploma & 43 & 50 & 1.00 & \\
Bachelor & 77 & 78 & $1.2(1.01-2.92)$ & $*$ \\
Work experience & & & & \\
1-10 & 109 & 121 & 1.00 & \\
11-20 & 11 & 7 & $1.7(1.34-4.66)$ & $*$ \\
Time allocation & & & & \\
Agree & 26 & 27 & 1.00 & \\
Disagree & 94 & 101 & $0.9(0.53-1.77)$ & $*$ \\
Nursing leadership & & & & \\
Satisfied & 73 & 43 & $3.1(1.83-5.16)$ & $1.9(1.04-3.82)$ \\
Not satisfied & 47 & 85 & 1.00 & 1.00 \\
Staff shortage & & & & \\
Agree & 16 & 92 & $0.06(0.03-0.12)$ & $0.07(0.03-0.13)$ \\
Disagree & 104 & 36 & 1.00 & 1.00 \\
Inadequate facilities & & & & 1.00 \\
Agree & 99 & 120 & $0.3(0.13-0.74)$ & $0.4(0.19-0.83)$ \\
Disagree & 21 & 8 & 1.00 & \\
\hline Not signficantin the & & & & \\
\hline
\end{tabular}

*Not significant in the multivariate analysis (back ward stepwise logistic regression) 
Respondents with work experience of 11-20 years had good knowledge when compared to those with work experience of $\leq 10$ years. Similar finding was reported in study conducted in Nigeria; where years of experience were significantly associated with clinical practice and knowledge [21]. Other study done in Spain on Nurses' knowledge and clinical practice of pressure ulcer care revealed that, the greater the working experience the higher the knowledge gained [22]. The reason might be nurses with more years of working experience have more chance to work with different professionals so that they can learn from their coworker's experience. Also since they have more prolonged exposure to patient care, they have greater chance to learn how to prevent pressure ulcer even from their own mistakes as compared to those who have less years of working experience.

Nurses who took formal training on pressure ulcer prevention were found to have good knowledge than those who had not. Similarly in a study conducted in Swedish healthcare to assess knowledge, attitude and practice of nursing staff on pressure ulcer prevention; nurses who had training were more knowledgeable than those who did not [23]. This might be due to the fact that training increases the chance of the trainees to get up to date information about pressure ulcer related preventions.

Staff shortage is one of the factors associated to nurse's practice in prevention of pressure ulcer. This study also favored the above claim in which, respondent's practice of pressure ulcer prevention was found to be poor which was less than $50 \%$. Similarly study conducted in England showed that, majority of the nurses reported lack of staff and time as barrier to implement effective care practices related to prevention of pressure ulcer [24]. The poor practice can be explained by the fact that, shortage of nursing staff limits the working time available for each patient's care. Especially in countries like Ethiopia where number of health professionals is near to the ground, inadequate nurse to patient ratio may limit the implementation of quality care related to pressure ulcer prevention.

In this study more than three fourth of nurses did not use a risk assessment scale. Similarly the study conducted in Sydney found that $79 \%$ of the nurses did not use any assessment tool to identify patients with at risk of pressure ulcer [25]. This can be explained by lack of evidence based nursing practice and in-service training on prevention of pressure ulcer.

Respondents who were satisfied with the nursing leadership had good practice as compared to those who were not. Possible reason for this result might be nurses who are satisfied with the nursing leadership are happier on their working environment, so that they are motivated to invest all their knowledge and experiences on practices related to prevention of pressure ulcer.
Inadequate facilities and equipments in the workplace were associated with poor practice on prevention of pressure ulcer. This might be due to the fact that limited access to adequate facilities and equipments may hinder nurse's motivation and ability to prevent patients from developing pressure ulcer.

Using a self reported questionnaire to examine the nurses' practice towards prevention of pressure ulcer was the main limitation of this study.

\section{Conclusions}

Nurses' knowledge and practice regarding prevention of pressure ulcer was found to be inadequate. Having higher educational status, attending formal training, being more experienced showed a positive and significant association with knowledge; whereas inadequate facilities and equipments, dissatisfaction with the nursing leadership and staff shortage and were found to be associated with poor practice of pressure ulcer prevention. Inservice training, upgrading courses and ensuring availability of the necessary facilities and equipments are some of the important steps to improve nurses' knowledge and practice regarding to prevention of pressure ulcer.

\section{Competing interests}

The authors declare that they have no competing interests.

\section{Authors' contributions}

NNY, FZA and SAF were involved in the design of the study, data analysis, and interpretation of the findings, report writing and manuscript preparation. YMA was involved in the design of the study, analysis and interpretation of the data, and review of the report. All authors read and approved the final manuscript.

\section{Acknowledgements}

Our heartfelt thank goes to University of Gondar for all expenses of the research work and all the study participants who voluntarily participated in this study.

\section{Author details}

${ }^{1}$ Emergency Department, Metema Hospital, Gondar, Ethiopia. ${ }^{2}$ Department of Nursing, University of Gondar, Gondar, Ethiopia. ${ }^{3}$ Department of Reproductive Health, Institute of Public health, University of Gondar, Gondar, Ethiopia.

${ }^{4}$ Department of Nursing, Wolaita Sodo University, Wolaita Sodo, Ethiopia.

Received: 8 November 2014 Accepted: 30 April 2015

Published online: 16 May 2015

\section{References}

1. Bours G, Halfens R, Abu-Saad H, Grol R. Prevalence, prevention, and treatment of pressure ulcers: descriptive study in 89 institutions in the Netherlands. Res Nurs Health. 2002;25(2):99-110.

2. Robinson, Maureen: Australian Council On Healthcare Standards:Primary Intention The Australian Journal Of Wound Management 2005, 13(3).

3. Fogerty M, Abumrad N, Nanney L, Arbogast P, Poulose B, Barbul A. Risk factors for pressure ulcers in acute care hospitals. Wound Repair Regen. 2008;16(1):11-8.

4. Thomas DR. Prevention and Treatment of Pressure Ulcers. J Am Med Dir Assoc. 2006;7(1):46-59.

5. Shiny V: Prevention of pressure ulcer for immobilized patients among care givers in Bapuji Hospital. Medical Surgical Nursing 2008:48

6. Bansal C, Scott R, Stewart D, Cockerell C. Decubitus ulcers: a review of the literature. Int J Dermatol. 2005;44(10):805-10. 
7. Oot-Giromini B, Bidwell F, Heller N, Parks M, Prebish E, Wicks P, et al. Pressure ulcer prevention versus treatment, comparative product cost study. Decubitus. 1989;2(3):52-4.

8. Eckman K. The prevalence of dermal ulcers among persons in the U.S. who have died. Decubitus. 1989;2(2):36-40.

9. Gorecki C, Brown J, Nelson E, Briggs M, Schoonhoven L, Dealey C, et al. Impact of pressure ulcers on quality of life in older patients: a systematic review. J Am Geriatr Soc. 2009;57(7):1175-83.

10. Black J, Girolami S, Woodbury MG, Hill M, Contreras-Ruiz J, Whitney JD, et al. Understanding Pressure Ulcer Research and Education Needs: A Comparison of the Association for the Advancement of Wound Care Pressure Ulcer Guideline Evidence Levels and Content Validity Scores. Ostomy Wound Management. 2011:57(11):22-35.

11. Gunningberg L, Lindholm C, Carlsson M, Sjödén P. Risk, prevention and treatment of pressure ulcers-nursing staff knowledge and documentation. Scand J Caring Sci. 2001;15(3):257-63.

12. Clark MB, Defloor T: Summary report on the prevalence of pressure ulcers. EPUAP Review. 2002

13. Beeckman D, Defloor T, Schoonhoven L, Vanderwee K. Knowledge and attitudes of nurses on pressure ulcer prevention: a cross-sectional multicenter study in Belgian hospitals. Worldviews Evid Based Nurs. 2011;8(3):166-76.

14. Kimberly C, Cheryl H, Polly J, Michelle M, Molly M, Misty O. PUPPI: The Pressure Ulcer Prevention Protocol Interventions. Am J Nurs. 2007;107(4):44-52.

15. Gedamu H, Hailu M, Amano A: Prevelence and associated factors of pressure ulcer among hospitalized patients at Felegehiwot Referal Hospital, Bahir Dar, Ethiopia. Advances in Nursing 2014:1-8.

16. Lyder CH, Ayello EA: Pressure Ulcers: A Patient Safety Issue. In: Patient Safety and Quality: An Evidence-Based Handbook for Nurses. edn. Edited by RG H; 2008

17. Rengin A, Merdiye S. Pressure ulcer prevention and management strategies in Turkey. J Wound Ostomy Continence Nurs. 2005;32(4):230-7.

18. Islam S: Knowledge, Attitude and Practice regarding Pressure Ulcer Prevention for Hospitalized Patients at Rajshahi Medical Collge Hospital in Bangladesh In.: Prince of Songkla University; 2010.

19. Enein NYAE, Zaghloul AA. Nurses' knowledge of prevention and management of pressure ulcer at a Health Insurance Hospital in Alexandria. Int J Nurs Pract. 2011;17(3):262-8.

20. Mockridge J, Anthony D. Nurses' knowledge about pressure sore treatment and healing. Nurs Stand. 1999;13(29):69-72.

21. Ilesanmi R, Ofi B, Adejumo P. Nurses' knowledge of pressure ulcer prevention in ogun state, Nigeria: results of a pilot survey. Ostomy Wound Management. 2012;58(2):24-32.

22. Pancorbo-Hidalgo P, García-Fernández F, López-Medina I, López-Ortega J. Pressure ulcer care in Spain: nurses' knowledge and clinical practice. J Adv Nurs. 2007;58(4):327-38.

23. Källman U, Suserud B. Knowledge, attitudes and practice among nursing staff concerning pressure ulcer prevention and treatment-a survey in a Swedish healthcare setting. Scand J Caring Sci. 2009;23(2):334-41.

24. Moore Z, Price P. Nurses' attitudes, behaviours and perceived barriers towards pressure ulcer prevention. J Clin Nurs. 2004;13(8):942-51.

25. Sharp C, Burr G, Broadbent M, Cummins M, Casey H, Merriman A. Pressure ulcer preventiom and care: A survey of current practice. J Qual Clin Pract. 2000;20(4):150-7.

\section{Submit your next manuscript to BioMed Central and take full advantage of:}

- Convenient online submission

- Thorough peer review

- No space constraints or color figure charges

- Immediate publication on acceptance

- Inclusion in PubMed, CAS, Scopus and Google Scholar

- Research which is freely available for redistribution 